\title{
PROPERTIES OF THE SPERM MOTILITY- STIMULATING COMPONENT DERIVED FROM HUMAN SERUM
}

\author{
B. D. BAVISTER \\ Department of Anatomy and Reproductive Biology, University of Hawaii \\ School of Medicine, 1960 East West Road, Honolulu, Hawaii 96822, U.S.A.
}

\section{(Received 8th November 1974)}

The dialysable heat-stable fraction of human serum stimulates the motility of hamster epididymal spermatozoa in vitro (Yanagimachi, 1970) and produces favourable conditions for capacitation, although the presence of protein is also required to stimulate the acrosome reaction efficiently (Yanagimachi, 1970; Morton \& Bavister, 1974). The active fraction from gel-filtered human serum was able to substitute for the motility-stimulating activity normally associated with the hamster cumulus mass (Bavister \& Morton, 1974), and it is reasonable to assume at present that the active substances from both sources are similar. Some properties of the serum-derived substance that may assist in its identification are described in the present communication.

Freshly collected male human serum was heated to $56^{\circ} \mathrm{C}$ for $30 \mathrm{~min}$, and then subjected to ultrafiltration (UM 20E filter, Amicon Gorporation). The filtrate was concentrated by freeze drying, and applied to Sephadex G-25 or G-10 columns $(73 \times 0.95 \mathrm{~cm})$. The columns were prepared and equilibrated with Dulbecco's phosphate-buffered salt solution, $\mathrm{pH} 7 \cdot 4$; the sample was eluted with the same solution. Fractions ( $1 \mathrm{ml}$ ) were collected, and $15 \mu \mathrm{l}$ aliquots were mixed with $35-\mu$ l droplets of a modified Tyrode's solution, containing 25 mM-sodium bicarbonate and $8 \mathrm{~mm}$-glucose, under paraffin oil in a plastic Petri dish (Falcon Plastics). The test drops were mixed with epididymal hamster spermatozoa (final concentration 1 to $2 \times 10^{6} / \mathrm{ml}$ ). After incubating under $5 \% \mathrm{CO}_{2}$ in air for several hours, sperm motility was assessed as previously described (Bavister, 1974).

When the ultrafiltrate of human serum was subjected to chromatography on medium grade Sephadex G-25, several peaks of motility-stimulating activity were found, all eluting within the included volume (Text-fig. 1a). Some retardation of the activity relative to the ferricyanide marker occurred, as found previously (Morton \& Bavister, 1974).

Samples of urine from the same donor as the serum already tested were filtered on the same G-25 column to determine whether the low molecular weight motility-stimulating component of human serum was excreted. The motility index showed at least two distinct peaks (Text-fig. lb). The activity was stable after heating at $100^{\circ} \mathrm{C}$ for $15 \mathrm{~min}$.

In a further series of experiments, serum ultrafiltrate was filtered on superfine grade Sephadex G-25. Only one activity peak was recovered from this column 


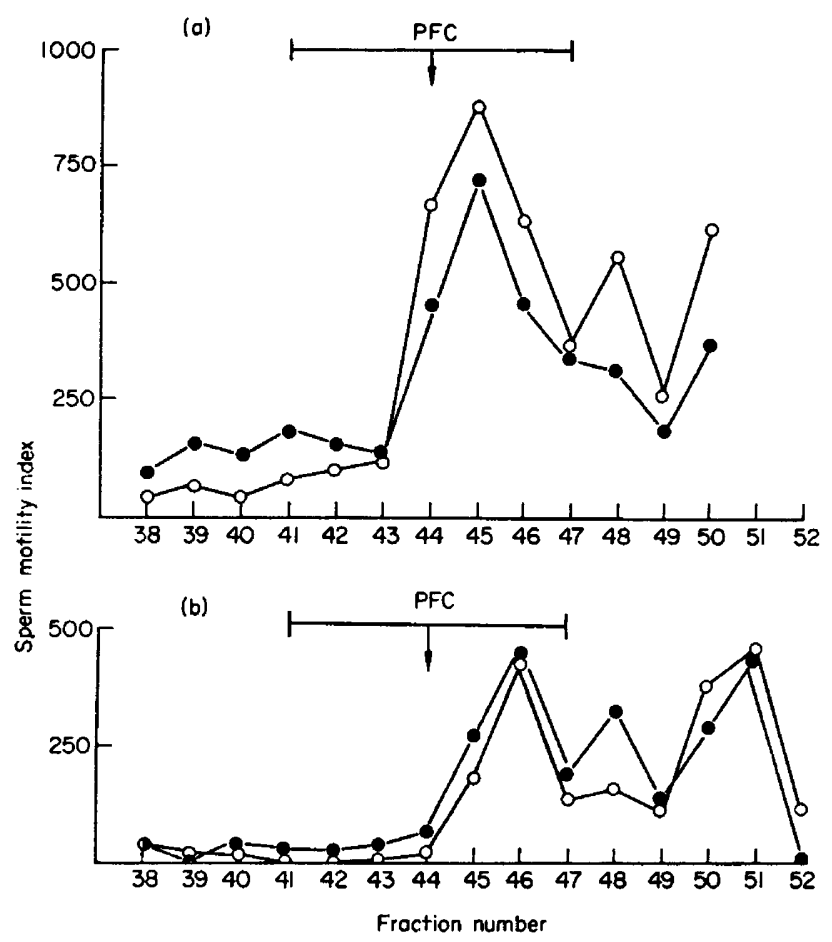

TeXT-Fig. 1. Motility of hamster spermatozoa $\left(1\right.$ to $\left.2 \times 10^{6} / \mathrm{ml}\right)$ incubated with Sephadex G-25 fractions of $1 \mathrm{ml}$ of (a) human serum and (b) human urine. The sperm-motility index was measured at $4 \mathrm{hr}(\bullet)$ and $6 \mathrm{hr}(0)$. Values given are the mean of two observations with spermatozoa from different males. Control values (phosphate-buffered salt solution) were 80 at both time intervals. The total elution volume of the potassium ferricyanide marker (PFG) is shown by the horizontal bars and the arrow marks the fraction with peak colour intensity.

(Text-fig. 2a). The pooled active fractions from this column contained $30 \mu \mathrm{g}$ peptides or amino acids/ml, measured by the method of Lowry, Rosebrough, Farr \& Randall (1951). Another sample of the ultrafiltrate was filtered on Sephadex G-10; the sperm motility-stimulating activity eluted between the high and the low molecular weight markers (Text-fig. 2b). Even allowing for some retardation on the gel, it is most likely that the active component penetrated the gel, suggesting a mol. wt lower than 700 , which is the exclusion limit of Sephadex G-10.

Attempts were made to define the molecular weight of the active component more closely by passing the serum UM 20E ultrafiltrate through another Amicon filter (UM 05) that retains substances with a mol. wt above 500. No activity was detected in the ultrafiltrate, but that in the residue was lost after flushing through with a large volume of Dulbecco's solution on a 'replacement' basis. This behaviour could be due to the active component binding to the filter; the UM 05 filter is negatively charged, so the component may have a net positive charge. Such a property is consistent with the retardation of activity on Sephadex, the dextran matrix of which possesses a slight negative charge. This retardation was considerable in previous experiments (Morton \& Bavister, 


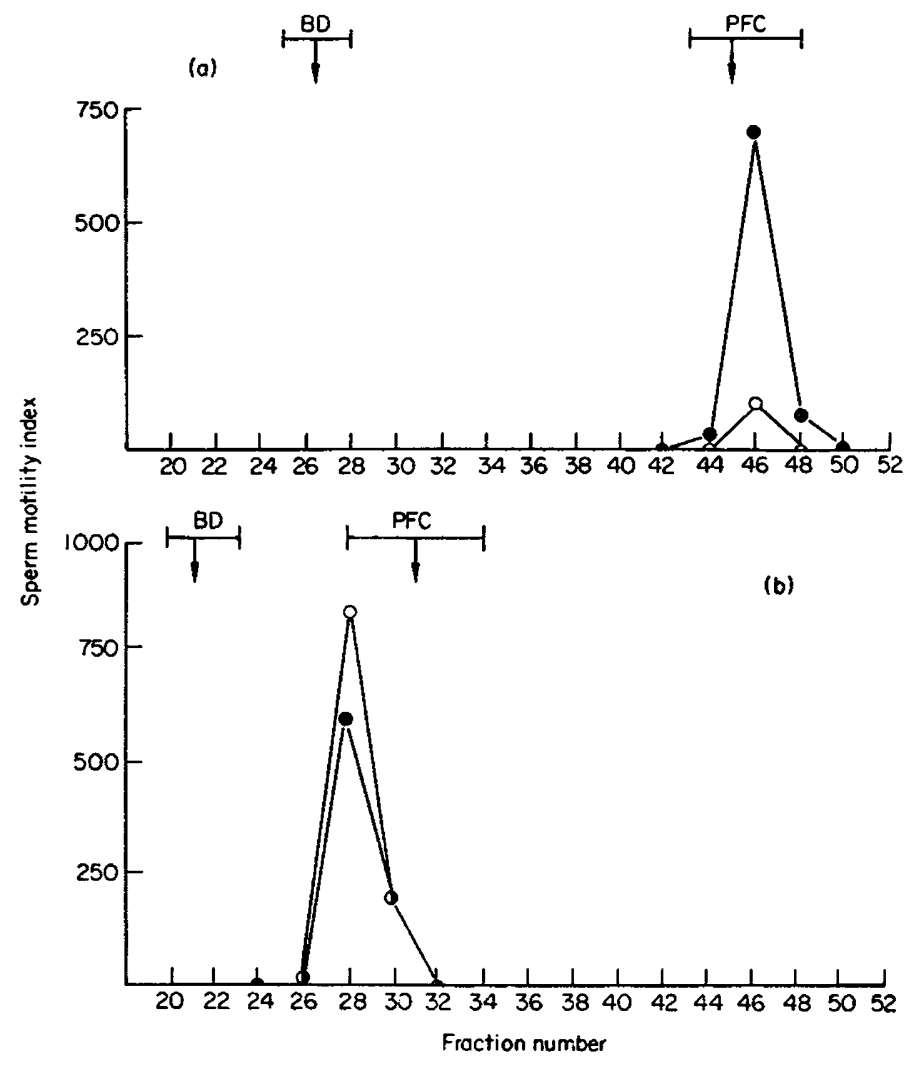

Texr-FIG. 2. Motility of hamster spermatozoa ( 1 to $2 \times 10^{6} / \mathrm{ml}$ ) incubated with Sephadex G-25 (a) and G-10 (b) fractions $(1 \mathrm{ml})$ of human serum. The sperm-motility index was measured at $4 \mathrm{hr}(\mathrm{e})$ and $6 \mathrm{hr}(0)$, and of all fractions outside the peaks it was zero. Values are the mean of two observations with spermatozoa from different males. The total elution volumes of the markers, blue dextran 2000 (BD) and potassium ferricyanide (PFG), are shown by horizontal bars and the arrows mark the fractions with peak colour intensity.

1974) in which a modified Tyrode's solution ( $\mathrm{pH} \mathrm{8.6)} \mathrm{was} \mathrm{used} \mathrm{to} \mathrm{elute} \mathrm{the}$ fractions, but less marked in the present series with $\mathrm{pH} 7.4$ phosphate-buffered medium, which would reduce the charge on the gel.

The molecular weight of the motility-stimulating component was also estimated by studying the elution of different molecular weight markers (amino acids) on the G-10 column. Proline and arginine had peak elution volumes of 27 and $29 \mathrm{ml}$, respectively, which are very close to the value for the motility-stimulating component $(28 \mathrm{ml}$ ). Glutamic acid eluted at $25 \mathrm{ml}$ (peak value). A precise estimate of the molecular weight of the active component cannot be obtained from this information because the component may well be retarded on Sephadex G-10, as it is on G-25. Nevertheless, it seems likely that the mol. wt is close to that of the amino acids tested.

Incubation of the pooled active G-25 fractions at $23^{\circ} \mathrm{C}$ for $15 \mathrm{~min}$ in 0.01 $\mathrm{N}-\mathrm{HCl}(\mathrm{pH} \mathrm{2.0)}$ destroyed most of the motility-stimulating activity, whereas considerable activity remained after incubation in $0.01 \mathrm{~N}-\mathrm{NaOH}(\mathrm{pH} 12.0)$ at 
$23^{\circ} \mathrm{C}$ for $15 \mathrm{~min}$. Heating at $100^{\circ} \mathrm{C}$ for $15 \mathrm{~min}$ in $0.01 \mathrm{~N}-\mathrm{NaOH}$, however, made the pooled material lethal to the spermatozoa. Another sample of the G-25 pool was mixed with 5 vols chloroform:methanol (2:1); the motility-stimulating activity was not removed from the aqueous phase by this treatment.

These preliminary results show that the human serum sperm motilitystimulating component has a mol. wt less than 700 , and probably between 100 and 200. The component is still active when excreted, but it is very sensitive to mild acid treatment. It is not soluble in chloroform-methanol, and there are indications that it is positively charged in alkaline solution. It is hoped that these findings will expedite the identification of the active molecule.

I am indebted to Dr Ryuzo Yanagimachi for his interest and encouragement, and I am grateful to Dr Jane Rogers for her helpful advice and for performing the protein measurement. This work was supported by a Research Fellowship from the Population Council, and by the Ford Foundation, and in part by grants awarded to Dr Yanagimachi by the Population Council, and the United States Public Health Service (HD-03402).

\section{REFERENGES}

Bavister, B. D. (1974) The effect of variations in culture conditions on the motility of hamster spermatozoa. 7. Reprod. Fert. 38, 431-440.

Bavister, B. D. \& MORTON, D. B. (1974) Separation of human serum components capable of inducing the acrosome reaction in hamster spermatozoa. J. Reprod. Fert. 40, 495-498.

Lowry, O. H., Rosebrough, N. J., FARR, A. L. \& Randall, R. J. (1951) Protein measurement with the Folin phenol reagent. F. biol. Chem. 193, 265-275.

Morton, D. B. \& Bavister, B. D. (1974) Fractionation of hamster sperm-capacitating components from human serum by gel filtration. 7 . Reprod. Fert. 40, 491-493.

YANAGIMAchi, R. (1970) In vitro capacitation of golden hamster spermatozoa by homologous and heterologous blood sera. Biol. Reprod. 3, 147-153. 